\title{
Less science, more policy at Amsterdam AIDS meeting
}

Basic research is giving way to policy at the Eighth International Conference on AIDS. have been received, basic science is down by 21 per cent from last year, and policy is up 53 per cent, organizers said last week.

The new figures reinforce the perceptions of many AIDS researchers that scientific exchange is giving way to discussions among activists and policy specialists. The meeting, to be held 19-24 July in Amsterdam, is expected to draw about 7,000 people, of whom only about half are researchers and clinicians. Nearly 5,000 papers will be presented, both in poster sessions and talks.

"The sheer size of the meeting has made it unsuitable for the kind of scientific exchange that a lot of us feel is useful," says Anthony Fauci, head of the AIDS programme at the US National Institutes of Health (NIH). Although he says the meeting does a good job of refocusing public attention on the issue, "from the standpoint of day-to-day scientist, I don't think it gives you the kind of scientific input you need. I don't go there expecting that I'll come back with really new insights."

Although clinical research is at about the same level as last year, epidemiological research is down by about 11 per cent. But Jonathan Mann, the conference organizer, says that the epidemiological research is Judging from the number of abstracts that

more rigorously scientific and less descriptive than in previous years.

Mann says the shift towards policy is both inevitable and desirable in order to draw attention to the social aspects of the issue. "Sometimes we lose sight of the need for breadth," he says. "If people are concerned only about the virus, there are other meetings at which they can learn more. But if they're concerned about the epidemic, this is the place to be."

A handful of sceptics who believe that human immunodeficiency virus has not been demonstrated to cause AIDS are holding their own meeting in Amsterdam next week to present theories that they say are being ignored by the main conference. But Mann says that the main meeting has always been willing to consider alternatives theories, and would usually accept them if they provide new information. Fauci adds that the general subject of co-factors, such as superantigens that contribute to immunodepression, are considered to be an important area of research.

"But whether you need a special meeting [on the subject] is another matter," he says. "I think these other immunopathic events are well represented at the regular conferences." So far, the alternative conference has signed up fewer than 100 participants.

Christopher Anderson

\section{More green for greener satellites}

London. Representatives of environmental interests want to have a greater say in planning the missions of Earth-observing satellites and the instruments they will carry in return for paying a larger share of the cost of such satellites.

An international organization representing most of the countries that are active in space met in London last week at the request of the British prime minister, John Major, to discuss how cooperation could improve the contributions that satellite data make to environmental management. In talks with officials from international environmental agencies, the members of the Committee for Earth Observations Satellites (CEOS) agreed to strengthen ties between the space industry and users of environmental data.

As major users of the satellite data, the environmental research community has been under pressure to contribute more money to the space industry. That need is likely to increase with the decline in support from military sources.

A dossier on existing and planned envi- ronmental space observation served as the basis for the discussion. An extract of this dossier will be sent to participants at next month's Earth Summit in Rio de Janeiro to raise awareness of the importance of satellite missions. Meanwhile, another document to be compiled by environmental researchers for the next CEOS meeting in December will set out ways to make the best use of satellite data and to identify the needs of its users.

These moves may not put more money into satellite programmes, but they could affect the way in which each organization pays for its share of the cost, with a greater proportion coming from the environmental sector. The meetings are also expected to give greater prominence to CEOS, leading perhaps to a permanent office and secretariat. The committee, with representatives from most of Europe, Japan, the United States, Canada, India, China, Russia and Brazil, is run from whichever country holds the committee chair. Britain is in the chair for 1992

Ian Mundell

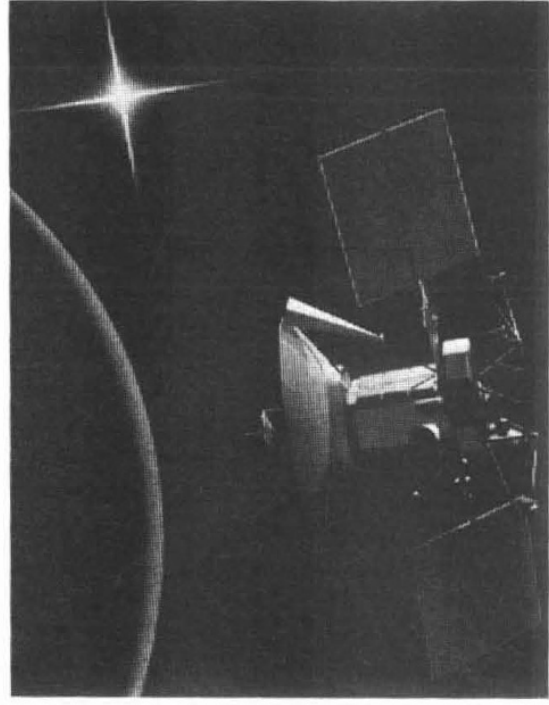

\section{Magellan team fights to extend mission}

Washington. Project managers for the Magellan radar mapper are cutting costs and writing letters to keep the spacecraft alive. Although the project is scheduled to end its mapping of Venus by September 1993, project scientists say they could wring another 18 months of science from the probe by cutting operating costs in half. But to do that, they need at least another $\$ 33$ million next year and must overcome both a failing transmitter and the opposition of the $\mathrm{Na}$ tional Aeronautics and Space Administration (NASA), which wants to end the project as planned.

"NASA's taking the position that we've already met our project goals and Magellan ought to be turned off", says James Scott, Magellan project manager at the Jet Propulsion Laboratory in Pasadena, California. But he and other project scientists believe that putting more spacecraft operations under computer control and cutting the staff from 270 to 170 will allow Magellan to operate at about half of its usual $\$ 40$ million annual cost.

NASA, however, wants to prove to Congress that it can keep to a budget, and has so far allocated only $\$ 10$ million for next year to complete the data analysis and produce a final report. Foiled internally, the Magellan team has now turned to outside pressure, appealing directly to members of Congress and to the vice president, Dan Quayle, who is head of the National Space Council.

But their chances are being hurt by the spacecraft's continuing technical problems. It is now operating on a backup transmitter, and even that has a failing part that is interfering with the data signal (see Nature 355, $190 ; 1992$ ). Even with "heroic measures" by ground-based receivers, Scott says, Magellan's data signal is almost unusable. "If we had a better signal, we'd have a better chance at funding," he says.

Christopher Anderson 